BUREAU OF ECONOMIC GEOLOGY

The University of Texas

Austin 12, Texas

JOHN T. LONSDALE, Director

Report of Investigations-No. 16

\title{
The Hazel Copper-Silver Mine, Culberson County, Texas
}

By

\author{
PETER T. FLAWN
}

August 1952 



\section{BUREAU OF ECONOMIC GEOLOGY}

The University of Texas

Austin 12, Texas

JOHN T. LONSDALE, Director

Report of Investigations-No. 16

\section{The Hazel Copper-Silver Mine, Culberson County, Texas \\ By \\ PETER T. FLAWN}

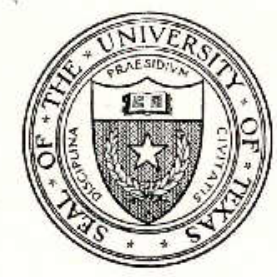





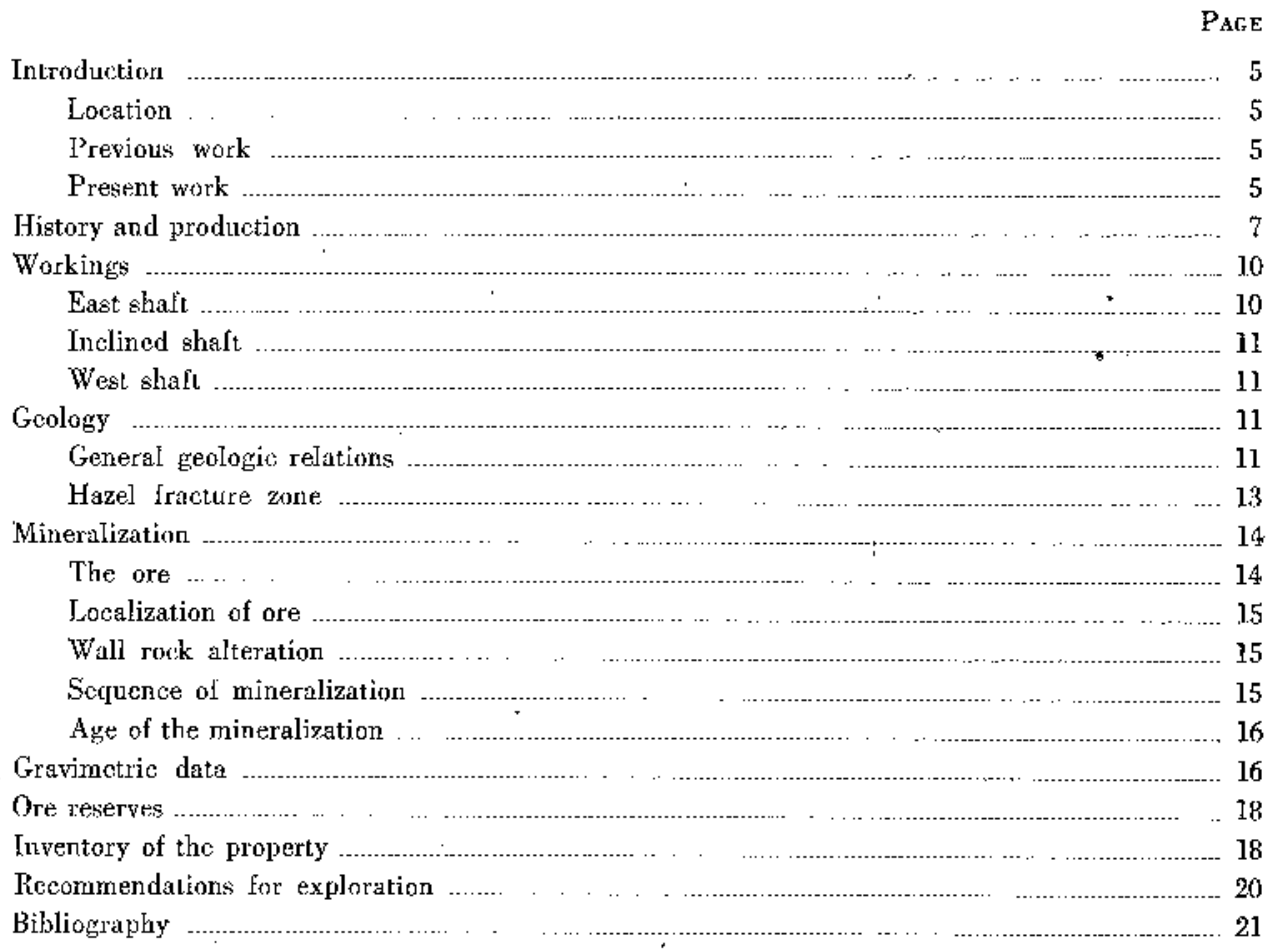

\section{ILLUSTRATIONS}

Frcukz:-

1. Index map of the Hazcl mine area, Culberson Connty, Texas . _ ................................... 6

2. Gravitational force map of Hazel mine ................... . . . . . . ............................................. 17

3. Gravitational force map of Marvin-Judson prospect ....................................................... 18

4. Diagram of gravity anomaly caused by leached zone ..................................................... 19

Plat'es (in pocket)--- .

I. Geologic and topographic map of the Hazel mine.

II. Vertical sections and level plans of the Hazel mine in 1891 (after Von Streeruwitz).

III. Map (after World Exploration Company) showing underground workings in Hazel mine.

VI. Generalized composite map of the Hazel. mine (after World Exploration Company and Sample and Gould).

V. Assay map of the Hazel mine (after World Exploration Company).

V. Gcologic map of the Hozel nine area.

VI. Photographs of the Hazel mine in 1891 and 1951

\section{TARLE-}

1. Recorded production from the Hazel mine aren 


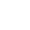




\section{THE HAZEL COPPER-SILVER MINE, CULBERSON COUNTY, TTXAS ${ }^{1}$}

Peter T. Flawn

\section{INTRODUCTION}

The Hazel mine is one of the oldest mines in Texas and has been the largest copper-producing property in the State. The mine has a recorded production of over 1 million pounds of copper and over $1 / 2$ million ounces of silver, and there are a number of years in which the mine was active but for which no figures are available. True production is in the neighborhood of 4 to 5 million ounces of silver and $1^{1 / 2}$ million pounds of copper. The Hazel mine is the most important of a group of mines and prospects known as the Allamoore-Van Horn copper district (Sample and Gould, 1945). This district lies within Culherson and Hudspeth counties in an area of pre-Cambrian rocks exposed bctween the scarp of the Sierra Diablo to the north and Beach and Baylor Mountains to the southeast and east. The district is bounded on the east and west by the approximate longitudes of Van Horn and Allamoore. The altitude is about 4,500 to 5,000 feet, climate is arid or semi-arid (generally less than 10 inches rain per ycar), and mining operations can be conducted all year. Water is obtained from wells or mine secps. Vegetation is of a desert typo and consists of various cacti, yucca, and thorny shrubs without suitable mine timber. The present freight rate from Allamoore to the El Paso smelter is $\$ 3.77$ per ton (plus 3 percent Federal tax) for ore valued at less than $\$ 75.00$ per ton.

Location.-The Hazel mine, which is located about 15 miles northwest of $\mathrm{Van}$ Horn, can bo reached by way of Van Horn or by way of Allamoore, although washouts on the latter route have made it impassable for conventional vehicles (fig. 1). From Van Horn one travels north on paved State highway No. 54 for 10.8 miles to a double earthern tank on the west side of the road, thence westward on' an unimproved ranch road for 3.5 miles to the mine. From Allamoore the route is north

\footnotetext{
Ipurt of the work for this paper was performed in con. nection with a reneareh project ittled "Copprer Depronits of the Allanoore-Van Horn Disltict, Tcxal," which wa undertuken by the wriler as a reserve offere member of tho

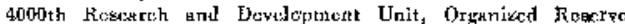
Serris, Anzhtin, 'Tохнн,
}

for 5 miles on a good gravel countymaintained road and then northeast over an unimproved ranch road that is at present badly washed. On both routes, however, the ranch roads are on the Hazel sandstone, which makes an excellent hard-bottomed road.

The mine property is a patented section of 667 acres (section 14, block 66, 'Г. 7 ., Texas \& Pacific Railroad survey, Culberson County, Texas) owned by the Hazel Mining and Milling Company of Dallas, Texas. (This company is represented by R. B. Stichter, Jr., 2024 Ross Ave., Dallas I, Texas.)

Previous work.-Von Streeruwitz (1890, 1891, 1892, 1893) described the Hazel mine during his early geologic reconnais. sance of Trans-Pecos Texas, and was the only gcologist, so far as is known, to ex. amine the deeper workings of the mine. His report and accompanying map in the Third Annual Report of the Texas Geological Survey (1892) are reproduced as a part of this paper (pp. 7-8 and PI. II). Richardson. (1914, p. 8) briefly described the mine during his work in the Van Horn guadrangle. P. B. King visited the Hazel mine several times between 1928 and 1939 during the course of his work on the Sierra Diablo region for the U. S. Geological Survey. His most thorough examination was made in 1938 , in company with S.J. Lasky of the Metals Section of the Survey. In 1944, as part of the war-time minerals explorations of the U. S. Geological Survey, the Hazel mine and others in the Allamoore -Van Horn district were studied by R. D. Sample and E. E. Gould. Much useful information on the various mines and prospects was obtained and is embodied in a report that has bcen available in open file since 1945. Evans (1943) made a preliminary survey of the mines and prospects in the Allamoore-Van Horn district prior to the work done by Sample and Gould, and some general observations on the area were published as a progress report.

Present work--The writer was engaged in areal geologic mapping in the general 
area in 1949 and 1950 and visited the property several times during that period. In 1951, assisted by S. M. Awalt, he spent two weeks on the property, mapped the surface area of the Hazel mine with telescopic alidade and plane table on a scale of 50 feet to the inch (Pl. I), and surveyed a network of stations for a gravity meter survey which was completed in January 1952 under the direction of Dr. V. E. Barnes, geologist, Bureau of Economic Geology. At the same time a gravity survey was made at the Marvin-Judson prospect about 1 mile due west of the Hazel mine where the Hazel fracture zone is intersected by a northwest-trending fault. Underground workings in both areas are inaccesible because of water. Most of the information herein is taken from a forthcoming report on the pre-Cambrian rocks of the Van Horn area by Dr. P. B. King, of the U. S. Geological Survey, and the writer. The present copper shortage makes it advisable to publish information on the Hazel mine as a separate report as an aid to further exploration in the area.

A great deal of the information in this paper came from local people who are familiar with the history of the mine. Particular thanks are due to Messrs. A. P. Williams and B. Melton of Van Horn. Mr. Williams was employed by the World Exploration Company during their period of operations as lessor and was himself a lessor during the late 1930's and early 1940 's. He provided a great deal of information on workings, grade of ore, and history. Maps of the underground workings

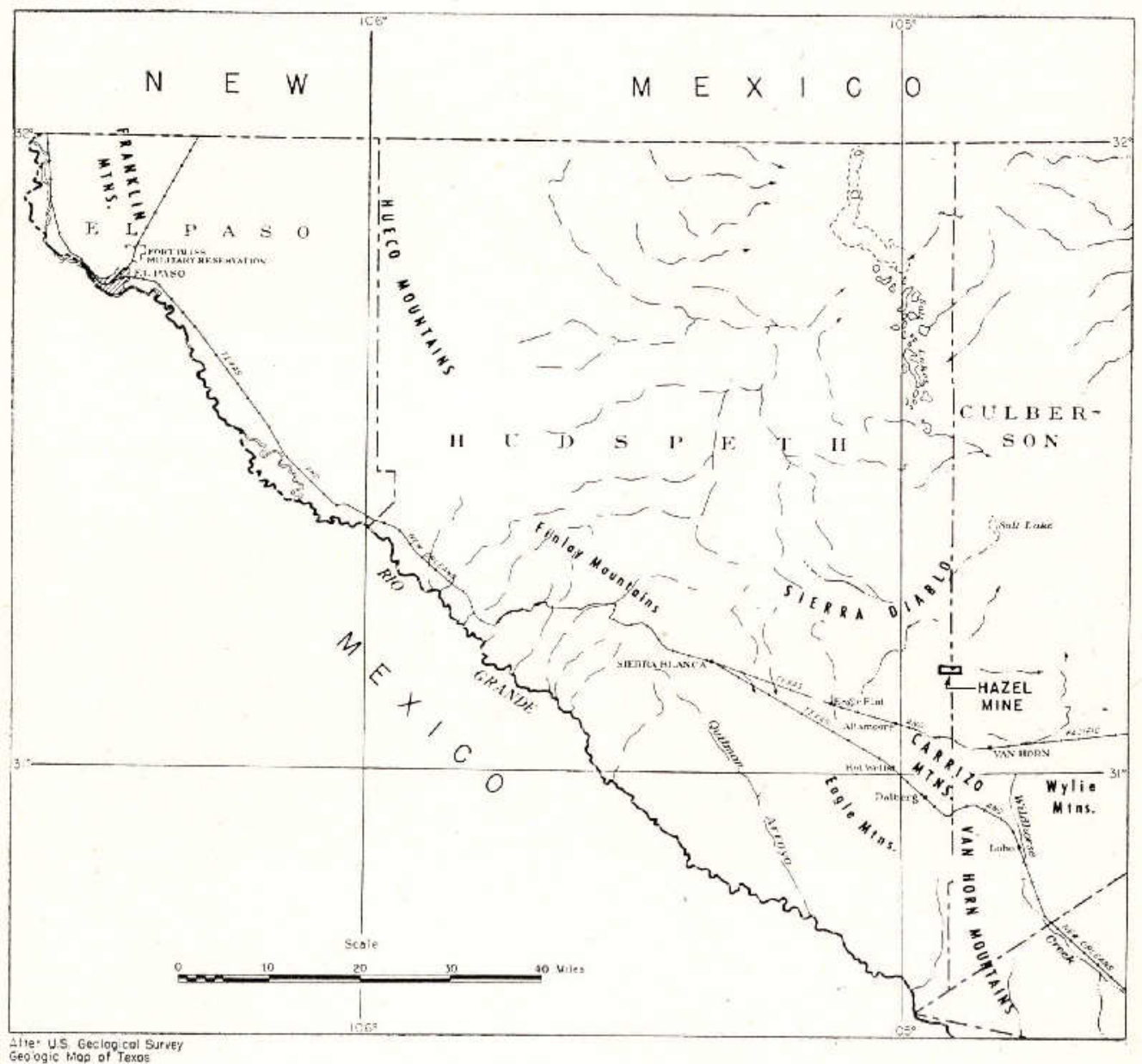

Fic. 1. Index map of the Hazel mine area. 
made by the World Exploration Company are reproduced in Plates III, IV, and V. Permission to publish these maps was given by Mr. R. B. Stichter of the Hazel Mining and Milling Company. The writer is grateful to Dr. P. B. King for making available his notes on the mine in advance of his preparation of a general report on the area. Mr. G. L. Evans of the Texas Memorial Museum added much valuable infor. mation from his unpublished notes on the area. This paper has gained much by addition of the section on "gravimetric data" (pp. 16-18) contributed by Dr. V. E. Barnes. In this regard special thanks are due Mr. Frederick Romberg, Manager Southern Division, Geophysical Service, Inc., Houston, Texas, for aiding in interpretation of the gravity data.

\section{HISTORY AND PRODUCTION}

The history of the Hazel mine was pieced together from information obtained from residents of Van Horn and from volumes of Mineral Resources of the United States and the Minerals Yearbook. The mine was first located by T. R. Owens in 1856 . Owens dug a shallow shaft about 20 feet deep (pit just north of Owens' house, Pl. I) and then was driven out of the country by hostile Apache Indians. Owens served as a Captain of Artillery in the Confederate Army during the Civil Wat and then returned to the Van Horn area, relocated the claim, and did some additional development work. According to Jim Bean of Van Horn, Texas, ,T. R. Owens and a man named Miller were located on the east end of the vein and $W . H$. Winn and C. S. Phinney were located on the west part of the vein in 1884 , and only a few prospect pits had been made previous to this date. Shortly thereafter the property was sold to Messrs. Shriver and Andrews of San Antonio.

Shriver and Andrews operated the property until 1896. with H. J. Clifford as mine superintendent, and this period was the most profitable in the mine's history. During this period as many as 4,00 workers were employed at the mine. The ore was hoisted by steam power, hand sorted, sacked, hauled by wagon to Carrizo (a station, now abandoned, on the Texas and Pacific Railroad 2 miles east of Allamoore) and shipped to a smelter in Pueblo, Colorado. There is a report that wood was cut on the
Diablo Plateau, north of and about 1,500 feet higher than the mine, for use as fuel to generate steam. Records are incomplete, but apparently a large tonnage of very high-grade ore was produced during the 1880 's and early '90's. Sample and Gould (1945, p. 19) state that about 80,000 tons of high-grade silver-copper ore was produced between about 1880 and 1895. In 1889 Von Streeruwitz (1890, p. 224) re. ported that 10 carloads a week were shipped for ten consecutive weeks. In 1890 Von Streeruwitz (1891, p. 698) stated that over 200 carloads of ore had been shipped from the mine and "vast quantities of low grade ores are on dump." In 1892 Von Streeruwitz (1893, p. I5l) stated:

The Hazel mine, at the foot of the Sierra Diablo. : . though not worked to its full capacity, clears, according to the statement of the owners, about $\$ 6,000$ per month from the argentiferous copper ores shipped, besides dumping immense quantities of ores, which are regarded low grade and not fit for shipment up to twentythree ounces of silver to the ton.

The writer has here reproduced Von Streexuwitz's complete description of the mine (1892, pp. 387-389) because it contains information on the deeper porlions of the vein not to be found in more recent reports, is of historical interest, and provides an excellent introduction for the present paper.

This mine is owned by Messrs. Shriver \& Andrews, of San Antonio, and is located about ten miles north of Allamore station on the Teras and Facific Railroad. The gangue is nearly perpendicular. Its width to a depth of about five hundred feet averages thirty-four feet, below this depth it widens to over forty feet. Its Iongitudinal extension may be traced for several miles, and its nearly nniform thickness is ascertaincd for eighteen hundred feet by the present workings shown in the accompanying sketch [P]. III. The gangue is in a fissure between a fine: graincd red sandstonc of probable Devonizn age, which also forms the walls, and which, in the vicinity of the gangue, is more or less metalliferous. The gangue has a whitish gray colored ca]. careous silicale, more or less impregnated through nearly its whole width with copper and silver sulphide and other metal combination, and numerous richer veinlets fill the space between the two principal veins known as the north and south veins.

The north vein runs from the outerop to the whole depth reached at the time I made the examination (June, 1891) down to five hundred and seventy-five feet practically perpendicularly. The south vein runs also perpendicularly to about one hundred and fifty feet, when it changes its dip slightly to the north and joins the north vein 
at about four bundred and fifty-feet from the surface.

At about three hundred feet from the surface another vein was struck on the south side, which joins the north vein at about five hundred feet. $A$ vein running in at three hundred and sixty fect through the south wall dips nearly paralled with the north vein to the full depth of the shaft, thus forming the south vein in the deeper parts of the mine. The strike of the gangue and the veins is nearly true east and west.

'The east shaft, on which most of the work has becn donc, is sunk on the south vein, resching (June, 1891) the depth of five hundred and seventy-five feet. From this shaft every fifty feet crosscuts are made to the north vein, determining the average width of the gangue from wall to wall to be about thirty-five feet. From these crossconts as well as directly from the shaft, more or less extensive drifts are run in the north and south veins, as shown by the accompanying sketw [P]. II] and the quantity and qualily of ore strnck by shafting and drifting in the veins and in pockets is highly promising to actual mining by stoping.

The west shaft is sunk on the north vein, eighteen hundred feet west of the east shaft, to a depth of three hundred and seventy-five feet and about three hundred and fifty feet of crosscuts and drifts worked from this shaft.

The middle shaft is three hondred leet west from the easi shaft, on the north vein. It is forty. two feet deep, and was last June a drift of about forty fcet in a material of the same character as the east shaft. 'The walls, as well as the gangue material in all the shafts and drifts, are somd and solid, and therefore very little timbering is required. Up to the time I made an examination of this mine no obnoxious gases were noticed, cxcept those resilting from the blasts, and very little water was struck in the shafts and drifts.

The principal ores of the main veins, as well as the veinlets and pockets, are silver-bcaring coppcr glance, gray copper, filver copper glance, silver g]ance, native gi]ver, chlorides with more or less copper. Lead, antimony and arsenites are found in traces, and traces of gold are not infrequent, and strongly ferruginous specimens assaycd ninetyfive hundredths of an ounce in gold and thirteen ounces in silver. The gray copper yields very high issays up to two thousand ounces in silver, and assays of some of the copper glance exceed six hundred ounces to the ton.

These as well as the other combinations mentioned above are deposited through the vein material (calc-silicates, frequently heavy spar) widening out occasionally to pockets of considerable size, and resulting in those orcs which sland shipping without concentration.

The whole gangue between the east and west shaft may be regarded as filled in with low grade ore through which the richer voins, pockets and veinlets are dispersed, and I rcgard it anything but an exaggeration to estimate the value of the ores in this mine as far as it js opened for work at twenty mitlion ounces of silvor.

There is no doubt that the greater part of the material on dump, not rich cnough to be shipped without concentration, is a low grade ore worth heing worked by lixiviation.
The red sandstone, in which the gangue runs to the depth of five hundred and seventy-five feet, will probably change into a crystalline schist or granitic rock at greater depth, and this change will in all probability favorably influence the orehearing.

There are numerous outcrops and prospects in the Sierra Carrizo, up to the clifls of the Sierra Diablo, just as promising as those of the Hazel mino were. The same can be said of the ontcrops and prospects of the Quitman. and Chinatli [Chinati] mountains. To develop them requires only capital, energy and experience, as proved by assays made in the laboratory of the Geological Survey.

From 1896 to about 1912 the mine was operated spasmodically without any con. sistent production, and during this period the property was purchased by a group of Dallas men. In about 1912 Sutton, Steele \& Steele began operations at the Hazel mine and built a 100 -ton reduction mill using a dry-concentration process. Equipment consisted of a Blake crusher, 12 Sutton, Stesle \& Stcole classifiers, 5 Sutton, Steele \& Steele concentration tables, and a Sutton, Steele \& Stecle dielectric separator. Crude ore and concentrates were shipped until May 191.4 when the mine closed. According to local sources, mill recovery was very poor. Sporadic shipments continued through 1917 when the mine fell idle.

In the early 1920 's the mine was leased by M. F. Drunzer who did some work underground but did not make any large shipments until 1926. In 1926 and 1927 Drunzer shipped 13,000 tons from the old dumps; this material averaged 0.5 percent copper and 9 ounces in silver.

In 1928 the World Exploration Company began operations at the Hazel mine. They reconditioned the buildings, built a 65 . foot headframe and a.150-ton ore bin, enlarged the old shaft to $4 \frac{1}{2}$ by $1.0^{1 / 2}$ feet in the clear, and timbered and lagged a three-compartment shaft to the 340-foot level of the old shaft: A 100-ton flotation mill was completed in Jantary 1930. Equip. rnent consisted of 2 Sturtevant erushers (still on the property), a Colorado Iron Works 6 by 6 ball mill, a Dorr duplex $5^{1 / 2}$ by 18-foot elassifier, 3 MacIntosh flotation machines, an Oliver filter, and 2 Dorr thickening tanks. The mill operated for about 8 months at about 31 tons per day. From May to October $1930,4,616$ lons of ore were treated to yield 238 tons of concentrate carrying 23,260 ounces in silver and 
102,587 pounds of copper. The mine and mill closed late in 1930, reportedly from lack of water.

In the early ' 30 's the mine was leased by A. P. Williams of Van Horn. Williams made small but fairly regular shipments until 1945. In 1947 Drunzer again leased the property and shipped a small lot of ore (454 tons carrying 2,731 ounces of silver and 6,983 pounds of copper).

History of production from the Hazel. mine is shown in Table I, but these figures

TABLE 1. Recorded production from the Hazel mine. ${ }^{2}$

\begin{tabular}{|c|c|c|c|}
\hline - Year & $\begin{array}{c}\text { Ore } \\
\text { (short tons) }\end{array}$ & $\begin{array}{l}\text { Copper } \\
\text { (pounds) }\end{array}$ & $\begin{array}{c}\text { Silver } \\
\text { (fine ounces) }\end{array}$ \\
\hline 1855-1899: & $?$ & $?$ & $?$ \\
\hline 1890 & $\mathrm{x}$ & $\mathrm{x}$ & {$[38,000$ dollars $]$} \\
\hline 1891 & 600 & 42,000 & 353,370 \\
\hline $1892-1905$ & $?$ & $?$ & $?$ \\
\hline 1906 & $\mathbf{x}$ & $x$ & $\mathbf{x}$ \\
\hline 1907 & 0 & 0 & 0 \\
\hline 1908 & 139 & 28,364 . & $\mathrm{x}$ \\
\hline 1909 & 0 & 0 & 0 \\
\hline 1910 & 0 & 0 & 0 \\
\hline 1911 & $\mathrm{x}$ & $x$ & $\mathbf{x}$ \\
\hline 1912 & $x$ & 721 & $\mathrm{x}$ \\
\hline 7913 & $\mathbf{x}$ & 34,665 & $\mathrm{x}$ \\
\hline 1914 & $x$ & 23,760 & $x$ \\
\hline 1915 & $\mathrm{x}$ & $x$ & $\mathrm{x}$ \\
\hline 1916 & $\mathrm{x}$ & 99,569 & $\mathrm{x}$ \\
\hline 1917 & $\mathrm{x}$ & $\mathbf{x}$ & $\mathrm{x}$ \\
\hline 191.8 & 0 & 0 & 0 \\
\hline 1919 & 0 & 0 & 0 \\
\hline 1920 & $\mathbf{x}$ & $x$ & $\mathbf{x}$ \\
\hline 1921.1925 & 0 & 0 & 0 \\
\hline 1926 & $\mathrm{x}$ & $10 ; 000$ approx. & $\mathbf{x}$ \\
\hline 1927 & $2,360 t$ & 19,676 & 27,365 \\
\hline 1928 & $14,810 \div$ & 180,000 approx. & 123,670 approx. \\
\hline 1929 & 6,8138 & 225,980 & 41,307 \\
\hline 1930 & 4,616 & 102,587 & 23,260 \\
\hline 1931 & 0 & 0 & 0 \\
\hline 1932 & 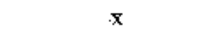 & $\mathrm{x}$ & $\mathrm{x}$ \\
\hline 1933 & 0 & 0 & 0 \\
\hline 1934 & $94 \mathrm{l}$ & 20,800 & 13,359 \\
\hline 1935 & 625 & 10,832 & 10,386 \\
\hline 1.936 & 223 & 7,079 & 3,251 \\
\hline 1937 & 186 & 4,192 & 2,291 \\
\hline 1938 & 373 & 7,217 & 8,214 \\
\hline 1939 & 1,742 & 25,459 & 32,690 \\
\hline 1940 & 1,055 & 33,000 & 18,093 \\
\hline 1941 & 268 & 12,799 & 1,815 \\
\hline 1942 & 469 & 28,242 & $2,08-1$ \\
\hline 1943 & 1,218 & 45,645 & 5,801 \\
\hline 1944 & 326 & 4,909 & 3,579 \\
\hline 1945 & 397 & 13,732 & 1,963 \\
\hline 1946 & 0 & 0 & 0 \\
\hline 1947 & 454 & 6,983 & 2,731 \\
\hline \multirow[t]{2}{*}{$1948-1950$} & 0 & 0 & 0 \\
\hline & $37,615 \|$ & $1,016,211$ & 674,991 \\
\hline
\end{tabular}

¿Data from O. S. Geol. Survey Mincral Resources of the Vnited Stalete, U. S. 13ur, Mines Mineraly Yearbook, and records of American Smoliting and Refining Company.

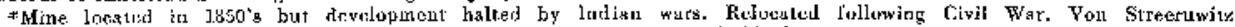

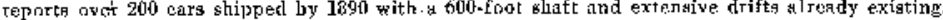

$?=$ nothing known ahout status of mine.

$\mathbf{x}=$ mine known to have shipped ore; figures lacking.

$0=$ mine known to have beca idli.

†Dry silver ore with less than 0,5 pereent copper from old durnp.

$\$ 10,000$ tons from oJd dnmp cartied 9 ounces silver and 0.24 percent copper; 4,810 tons siliceous orc from underground curried 7.63 ounces gilper and 1.53 pertunt copper.

Syrcludes 238.5 tons of concentrater.

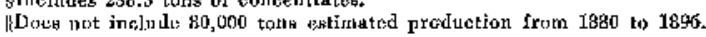


can be regarded as an absolute minimum hecause no records remain of the mine's most profitable years. Some estimate of the true production can be made by analysis of Table $I$ in the light of other data, and this is facilitated by dividing the production into an early period (before 1895) of high-grade ores and a later period (subsequent to 1895) of mostly low-grade ores. Examination of the early period shows that in 1891, 600 tons of ore contained 42,000 pounds copper and 353,370 ounces silver, or 7 pounds copper and 588.9 ounces silver per ton. Sample and Gould (1945, p. 19) estimated that 80,000 tons of high-grade silver and copper ores were produced from 1.890 to 1885 , and Von Streeruwitz stated that the break betwcen shipping ore and tailings during this period was 23 ounces silver per ton. Thus an assumption that this 80,000 tons of ore averaged 10 pounds copper and 50 ounces silver per ton does not seem unreasonable. This would give a total of 800,000 pounds copper and 4,000,000 ounces silver during the early period. 'The more complete records for the years subsequent to 1895 show a minimum production of 974,211 pounds copper and 321,621 ounces silver, and the total is about $1,774,000$ pounds copper and 4,322,000 ounces silver.

\section{WORKINGS}

Hazel mine workings are by far the most extensive underground workings in the area. There are three main shafts with a considerable length of drifts and cross-cuts and two open stopes (Pls. II, III, IV). During the last two decades the deeper workings of the mine have been full of water, apparently as a result of seep and run-off rather than underground flow, but the water has been lowered by pumping during intermittent operations. The mine has not been worked below the 400-foot level since about 1900 and has been under water since that time. In 1938 the water level stood at 175 feet in the East shaft and at higher levels in some of the adjacent shafts; in 1944, the water level was 165 feet in the East shaft but was pumped out to 225 feet the following year; in 1952 the water stood within 30 feet of the surface. These high-water levels have prevented extensive underground examination, so that a considerable amount of the descriptions which follow have of necessity been taken from oral reports and early records. This is particularly unfortunate in the case of the Hazel mine because the vein on the outcrop is poorly developed compared to the vein at depth.

East shaft.-The East shaft has been the most important entry in the mine's history and had reached a depth of 575 feet at the time of Von Streeruwitz' examination in $189 \mathrm{l}$. This shaft was deepened to 746 feet before 1900 and is at present the site of the headframe and hoist house. The minc has not been worked below a depth of about 400 feet (6th level) since the early 1.900 's, and the only information on the lower levels of the mine is given in Von Streeruwitz' early map (Pl. II). He shows drifting and cross-cutting on ten levels which are separated by intervals of some 60 or 70 feet. The upper six levels were included in the reconditioning work done by the World Exploration Company in 1928. According to Von Streeruwitz there was about 600 feet of drifts and cross-cuts on the 7 th through 10th levels in 1891 , and in all probability there was not a great deal of additional work done on these lower levels between 1891 and 1896 when continuous operations ceased. Most of the high-grade ore in the mine came from the first four levels -above 200 feet. Robbing of pillars and gouging operations have reportedly left the upper four levels of the mine in a dangerous condition. The collar and lagging at the top of this East shaft is rotted and weakened and would have to be repaired before there could be a renowal of operations from this entry.

Two stopes were worked through this shaft. The East stope is reported to be 200 feet deep and was "shrunk," at least in part, through the 4th level (200 feet). The West stope is connected to the East shaft on the 2nd level. Both of these stopes are shrinkage stopes that are open at the sur. face. The West stope is reported to have contained sporadic pockets of silver ore assaying as much as 1,800 to 2,000 ounces per ton, and most of the high-grade silver ore produced from the mine came from these two stopes.

Most of the dump that now surrounds the East shaft is the product of operations 
subsequent to 1928. The old dumps constituted low-grade ore and were shipped to the smelter prior to that date.

Inclined shaft.-About 600 feet west of the East shaft is a steeply inclined shaft about 200 feet deep. This shaft intersects drifts on the $3 \mathrm{rd}$ and 4 th levels. The date of completion of this shaft is not known, but it was not in existence in the 1890's when Von Streeruwitz reported on the property.

West shaft.-The West shaft is 1,800 feet west of the East shaft. At the time of Von Streeruwitz' visit (1891) this vertical shaft had been sunk to a depth of 375 feet, and about 350 feet of drifts and crosscuts were worked from it. There was never a great deal of additional work done on this shaft, although Evans ${ }^{3}$ reports a 25foot stope west of the entry. On the surface this shaft is a timbered double-compartment shaft, although it is not known to what depth the timbering extends. No headframe is present, and the shaft is surrounded by its original dump. The shaft was not sunk in ore, and the values in the dump material are low.

There are many other pits and shallow shafts between the East and West shafts. About 150 feet east of the West shaft is the timbered Bonanza shaft with a concreted ventilation raise 50 feet farther east. This shaft was sunk on rich chalcocite ore, and the surrounding dump should be assayed. The workings from this shaft consist of small stopes extending east and west about 50 feet and reportedly connecting with the West shaft. (As shown on the World Exploration Company's map, Pl. III, this Bonanza shaft is erroneously shown to be 375 feet deep; this figure actually applies to the West shaft, about 150 feet to the west.) About 350 feet west of the East shaft is an old vertical shaft known as Middle shaft which Von Streeruwitz in 1891 reported as 42 feet deep with 40 feet of drift. This shaft is located on the southeast corner of the large open stope.

At the time of the writer's examination of the property the workings were filled with seep and run-off water to within about 30 feet of the surface. However, there is a noticeable difference in the water level in the separated workings, and this attests to

\footnotetext{
Personal communication from G. L. Evans, Texas Memorial Museum, 1951.
}

the tight impermeable nature of the sandstone and vein. The workings are reportedly in a poor and even dangerous condition. The later operators robbed pillars and dumped waste in stopes, cross-cuts, and down the shaft.

\section{GEOLOGY}

General geologic relations.-The Hazel mine is located on an east-west fracture zone in the late pre-Cambrian Hazel formation. The Hazel formation here is a very fine-grained, compact, closely jointed, minutely cross-bedded, homogeneous red sandstone and siltstone that strikes northwest and dips gently southwest on both sides of the fissure. The general geology of the area is shown in Plate VI, a geologic map made by P. B. King using an enlarged U. S. Geological Survey aerial photograph as a base. The Hazel vein stands out on the aerial photograph as a discolored zone that can be traced for over 3 miles west of the main workings, which are located on the approximate east end of the outeropping vein. Other attempts to exploit this vein were made at the Marvin-Judson prospect, 1 mile west of the Hazel mine, and at the Mohawk mine, 3 miles west of the Hazel mine.

Immediately north of the mine the Hazel formation is unconformably overlain by the Hueco limestone (Permian Wolfcamp). The limestone forms a prominent cliff (Pl. VII) that marks the southern scarp of the Sierra Diablo. Southeast of the mine, in the Beach Mountains, the Hazel formation is unconformably overlain by the preCambrian (?) Van Horn sandstone and a lower Paleozoic section. To the southwest the Hazel formation is thrown into complex folds with the Allamoore formation (pre-Cambrian) which lies stratigraphically beneath it. Boulders and cobbles of Allamoore limestone occur in conglomerate beds interbedded in the Hazel sandstone in the country a mile or two south of the mine, but no conglomerate is present near the mine itself. For references on the general geology of the area, see King $(1935,1940,1944,1945,1949)$ and a forthcoming report by King and Flawn.

For exploration purposes it would be desirable to know the thickness of the Hazel formation at the Hazel mine, because 


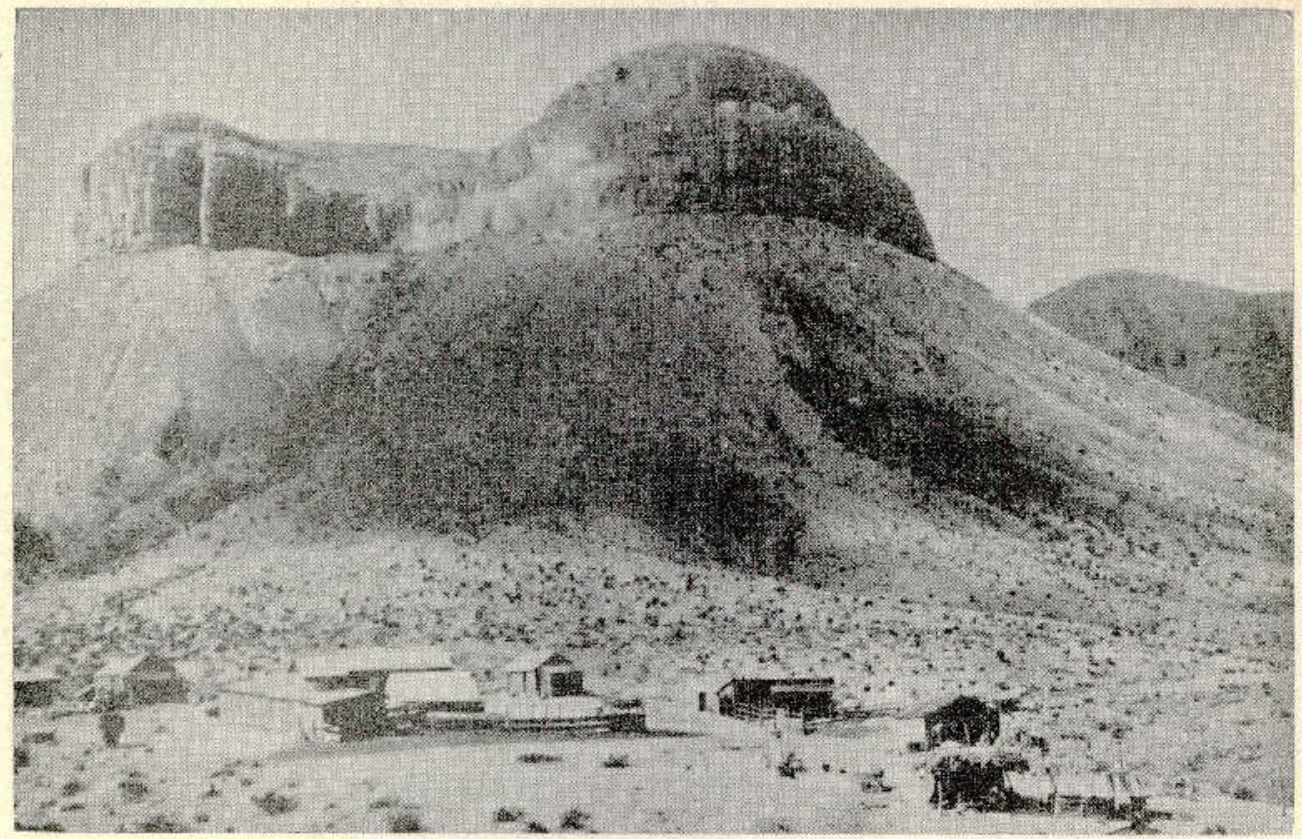

(A) The Hazel mine in 1889 (reproduced from a photograph by Rogers; Von Streeruwitz (1890), opposite p. 224).

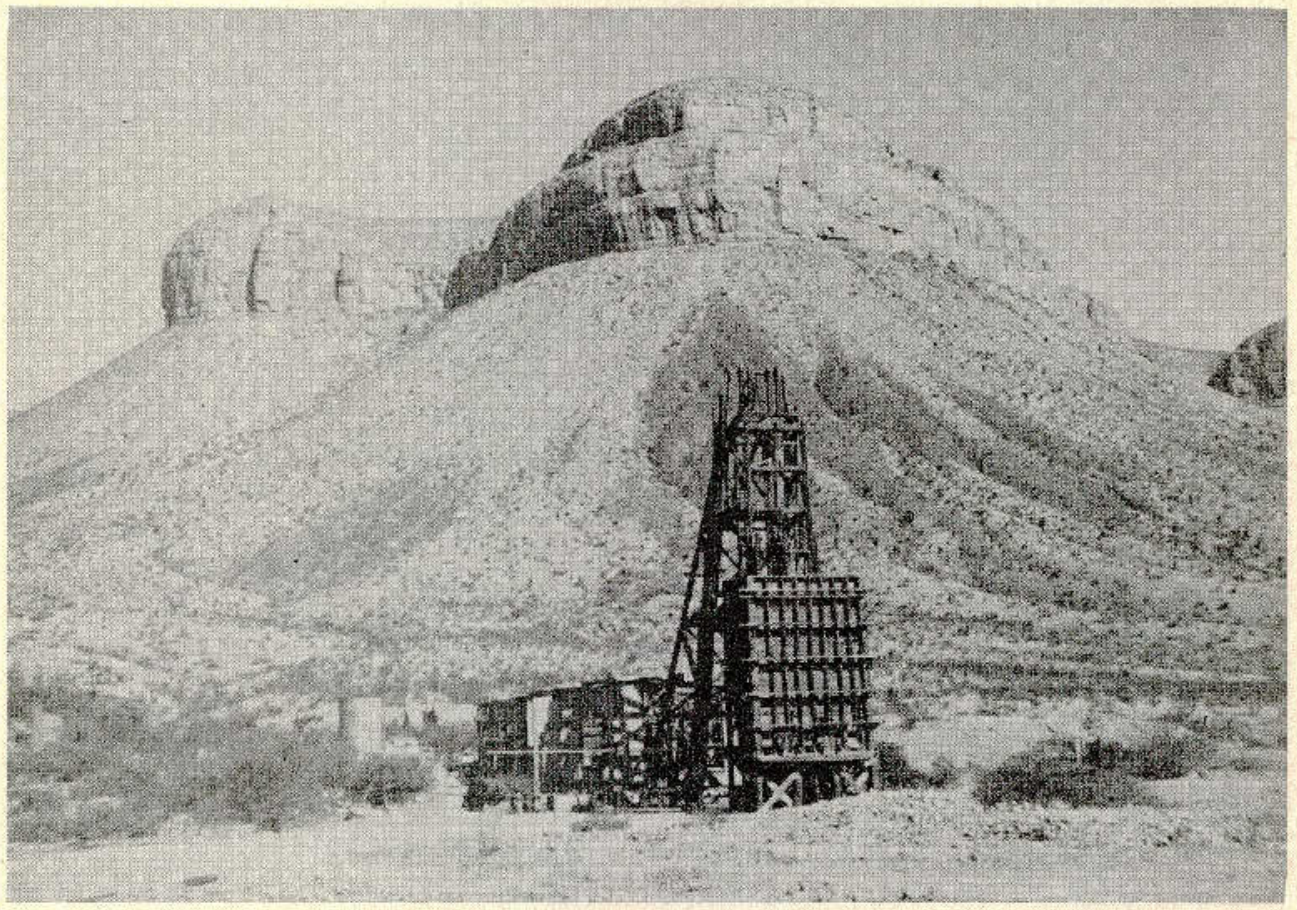

(B) The Hazel mine in 1951, view just east of that in (A) above. Compare with (A) above and note the increase in creosote bush and decrease in grasses. Photograph taken by P. T. Flawn, 1951. 
the lower conlact of the formation, which where cxposed to the south. is a surface of movement, may have influenced ore de. position. Unfortunately there is only very tenuous evidence on this point. King (un. published notes) has remarked that:

The IInze] is clearly a very thick formalion, but structutial relations are such that only incomplete estimates of thickness can be made. Extending nortliward from the Allamoore formation in the central Streeruwitz Hills there appears to be a continuous, steeply dipping succession at least 5,000 feet thick; of this, more than half is conglomerate. On the eastern scarp of the Sierra Ijiablo near the Pecosi prospect . . . . at least 2,250 fect of gently dipping sandstone is exposed.

At the Hazel mine there is no conglomerate exposed and the outcropping sandstone is apparently within the upper part of the Hazel formation. The East shaft of the Hazel mine reaches a depth of about 745 feet, and the sandstone wall rock apparcnlly extends unchanged to the bottom of the shaft, which was reported to be in "granite." G. L. Evans (oral communication, March 1952) stated that as described to him by a local miner, this "granite" was plainly the conglomerate which occurs in the lower part of the Hazel formation. Concerning the thickness of the conglomerate King (unpublished notes) says:

In the central Strecruwite Hills, next to the southern outcrop helt of the Allamoore formation, conglomeratic beds are at least 3,000 feet thick, of which the lower half is solid conglomerate, and the upper half is interbedded conglomerate and sandstone. Conglomexate of similar struccural relations in the southern Millican Hills is about 2,000 feet thick.

Thus, untess unrecognized structural relationships exist, the lower part of the Hazel formation, comprising 2,000 to 3,000 feet of conglomerate, must be penetrated before the bottom contact of the formation is reached.

'Two definite structural trends marked by northwest-trending faults and east-west trending fractures are present in the general area (Pl. VI). The east-west Hazel fracture zone is intersected by a northwesttrending fault about 1 mile west of the Hazel mine at the Marvin Judson prospect. The southwest side of the fault has apparently moved northwest, but there is no visible displacement of the Hazel fracture zone or the fault at the point of intersection, and the rock on either side of the Hazel fracture zone maintains a northwest strike and a gentle southwest. dip. Evidently the nearly vertical Hazel fracture zone is younger than the northwest-trending fault or at least younger than the strike-slip movement along the northwest-trending fault. Tertiary normal faulting in the general region is characterized by similar northwest-trending and east-west trending faults, and it is possible that the Hazel fracture zone and the northwest-trending fault that intersects it are Tertiary structures, although the horizontal displacement in the northwest-trending fault is not characteristic of Tertiary faults in this area. King (personal communication, January 1952) states that the west-northwest fault system has had a long and complex history. $\mathrm{He}$ notes Tcrtiary vertical movements, several periods of pre-Tertiary vertical movements, and still older strike-slip movements that may be late-pre-Cambrian.

Hazel fracture zone.-In the vicinity of the Hazel mine the Hazel fracture zone shows up on aerial photographs of the area as a series of sub-paralleI and en échelon fractures.

The fractured zone is marked by bleachod, brecciated, and altered sandstone. The altered rock is yellow to gray and stands out clearly against the red sandstone that forms the walls. There is no evidence of large-scale displacement along this fracture zone, but the wriler is informed that slickensides and mullion structures are visible underground. The main. east-west fracture zone is intersected by a number of small northeast-trending fracturcs which have apparently been important in localization of the ore. At the surface the altered yellow sandstone that constitutes the gangue is generally less than 7 feet wide and occurs in discontinuous palches and feathery projections. Underground, however, the altered rock comes in solidly between distinct red sandstone walls and widens steadily downward until, according to Von Streeruwitz, it attains a thickness of over 40 feet at a depth of 500 feet. Evidently the present surface of the ground intersects the top of the fissure system. 


\section{MINERALIZATION}

The ore.-...The following copper and silver-bearing minerals from the Hazel mine were reported by Von Streeruwitz:

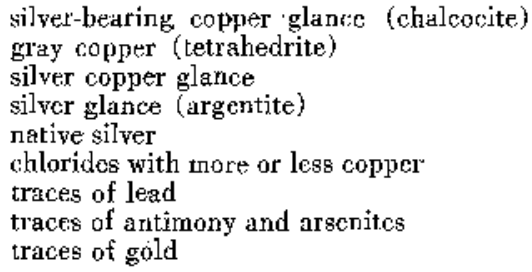

S. J. Lasky (lelter to P. B. King, August 25, 1938; memorandum to P. B. King, October 28, 1938) reported that the steely mineral occurring as threads in the bleached rock is tenrantite, and specimens given to him and said to have come from the upper levels of the mine were steely chalcocite. Lasky also noted pyrite, galena, chalcopyrite, and a trace of bornite. Massive sulfide specimens collected by the writer on a dump near the West shalt were steely chalcocite. Three polished sections. of these dump samples from the West shaft were examined by the writer, and all consist largely of anisotropic chalcocite intimately penetrating and penetrated by barite. Fine brecciation and flowage structures are present in all three samples. Small irregular patches of bornite $(0.02$ $\mathrm{mm}$ ) occur within the chalcocite and are commonly separted from the chalcocite by a very thin border of gray mineral that is probably tetrahedrite-tennankite. Small. masses of covellite and tiny clusters of pyrite grains occur sporadically within the chalcocite and barite. Gangue minerals are calcite, barite, and quarlz. The quarlz is probably from the original sandstone.

Three polished sections of massive metal. lic fragments from the dump near the East shaft show a fine intergrowth (in part a microbreccia) of barite and a large number of metallic minerals. Chalcocite, tetrahedrite-tennantite (?), bornite, an unidentified strongly anisotropic brownishgray minieral, chalcopyrite, native silver, pyrite, marcasite, covellite, and an unidentified pale silver-white mineral (antimony?) aro present in approximately that order of abundance. The extremely fine grain size precludes microchemical analysis of the unknowns with the facilities available to the writer. Pyrite is apparently early and occurs in fractured grains which locally have been drawn out into Ienses. Chalcopyrite is in part early in fractured grains and in part late in narrow veinlets parallel to the flowage structure. Bornite occurs in spongy intergrowths with tetrahedrite-tennantite (?) and in veinlets parallel to existing flow structure. Chalcocite and the unidentified brownish-gray mineral seem to have come in late and "healed" the microbreccia, but the relationship of the chalcocite and brownish-gray mineral to the bornite-tetrahedrite-tennantite (?) intergrowths is not apparent. Native silver was the last ore mineral deposited and occurs in fractures that crosscut the earlier structures and grain boundaries. Marcasite covellite, and the unidentified pale silver-white mineral (antimony?) are present in minute quantities. Possibly some argentite is included in what is here called tetrahedrite-tennantite (?) (see p. 8) because the two minerals, both gray, are not easily dislinguished in such a fine-grained intergrowth. A thorougl study of the relationship of mineral paragenesis and fracturing or brecciation would perhaps aid in the scarch for high-grade silver ore in this mine.

Assays of Hazel mine ores are erratic and characterized by sporadic high silver values. The bulk of the high-grade silver ore came from the open stope west of the main shaft (West stope) where assays as high as 1,800 to 2,000 ounces per ton were reported. As indicated by the polished section study, tetrahedrite-lennantite (?) and native silver were important ore minerals in this part of the vein. Silver values drop to the west, and in the vicinity of the West shaft the principal ore mineral is chalcocite. Most of the bleached altered sandstone gangue between the East and West shafts assays I to 5 ounces in silver. An unsubstantiated report handed down from one of the early miners in the Hazel mine states that work on the main shaft stopped at 746 feet because of a decrease in sílver values downward. In the early days of the mine it was necessary to have a silver content above 23 ounces per ton to make shipping ore. The copper content of the ore supposedly remained fairly steady with increased depth.

Lasky (memorandum to P. B. King, October 28, 1938) reports on a black rock found in certain parts of the vein. 
The black rock that accompanies the stronger parts of the vein and that the miners say they use as a guide to ore, seems to be crushed rock and vein matter that owes its color to comminuled sulphides. . . . . . . . some of this bluck rock has a streaked structure resembling flowage and has about the texture and hardncss of some slate. In it are breccia pieces of both vein matter and of wall rock, and the adjacent wall rock is also brecciated in some places. A thin section of the black rock shows breccia pieces of rock and calcite, und grains of quartz (presumably from the original sandstone), in a cryptocrystalline matrix made gray to black by opaque dust. Examination of a polished section cut from the same fragment as the thin section fails to give any clue as to the identity of the opaque dust, the only mineral identifiable being the irregular gxains of pyrite that can be seen in the hand specimen, but I obtained a yood microchemicaI test for arsenic. Though a test for copper is negative, the positive test for arsenic would scem to indicate that some of the opaque dust is lennantite, presumably powdered so fine as not to be apparent on polished surface, perhaps because of having been gouged out during polithing.

Localization of ore.-The copper and silver-bearing minerals occur in narrow veinlets and stringers in the yellow gangue. In the vicinity of the East shaft there are two main veins within the fractured zone, the north vein and the south vein. According to Von Streeruwitz (1892, p. 388), the north vein is essentially vertical throughout the depth of the shaft (575 feet in 1891). The south vein is perpendicular from the outcrop to a depth of about 150 feet, where it changes to a steep north dip and joins the north vein at a depth of about 450 feet. At a depth of about 300 feet a third vein comes in from the south, dips stceply north, and joins the two main veins at a depth of about 500 feet, just below the 8 th level (Pl. II). The gangue between these veins is brecciated and filled with narrow anastomosing veinlets of silver and copper sulfides and stulpho-salts. A. P. Williams of Van Horn stated that in the drifts west of the East shaft the main metal-bearing veins averaged 2 to 3 inches wide with small pockets of rich ore where the east-west veins were intersected by cross fractures. In the open stope west of the main shaft there was a massive body of silver-copper minerals and barite 2 to 3 feet wide. In this area the east-west veins were intersected by a number of northeasttrending fractures that wore also mineralized.

The interlacing ore veinlets pinch and swell along the strike, resulting in ore pockets and relatively barren areas, and it is this that has made it difficult to "stay in ore" or to calculate reserves at the Hazel mine. The ore is sharply contained within the massive sandstone walls bounding the fracture zone and is not disseminated within the country rock to any noticeable degree.

P. B. King (unpublished notes) describes a rather typical cross section of the fracture zone from an open cut 200 feet east of the East shaft.

The vein is nearly a vertical fracture about 7 fcet widc, consisting of main fractures on esch side, connected by diagonal, interlacing crossfractures, enclosing moderately crushed country rock. Decolorization of the red sandstone exlends I to 2 feet away from the vein on each side. Be. tween the bordering fractures, decolorization is irregular. Mineralization consists of barite, with some chalcopyrite and tetrahedrite, which fill cracks 1 to 3 inches wide. The metallic minerals form only a small percent of the total volume.

Wall rock alteration.-'I'wo types of altered Hazel sandstone are present in the fracture zone: a soft, crumbly yellow to buff rock and a hard gray rock carrying some metallic minerals visible as minute black spots. It is probable that alteration proceeded in that sequence; first a bleaching of the red iron oxide color and leaching of the cement of the red sandstone and then, in some places, an impregnation of metallic minerals. Both alteration types are veined by calcite and barite.

Sequence of mineralization.-The writer was unable to visit the mine underground and therefore unable to collect a suite of samples for a detailed paragenesis study. Ilowever, some general statements can be made. Brecciation and movement in the Hazel fracture zone occurred before and after the mineralization. This is demonstrated by brecciated ore made up of angular fragments of wall rock and ore minerals cemented by calcite (noted by King) and the finely comminuted opaque "dust" noted by Lasky in the black "slaty" rock that commonly accompanies the ore.

Barite is also a guide to ore in the mine, and the relationship of barite to the coppersilver minerals is worthy of study. Barite invariably occurs with ore, but the converse is not true. The writer has observed breccia fragments of gray sandstone surrounded by a thin coating of metallic min. erals and the whole completely enveloped 
by barite. The space between the baritecoated fragments was then filled by metal. lic minerals. Apparently, the copper-silver mineralization both preceded and followed barite mineralization, allhough there may have been changes in the nature of the precipitated ore minerals over the period of deposition (perhaps a change from tennantjte-tetrahedrite during early stages to chalcocite in the final stage).

Age of the mineralization.-The age of the mineralization at the Hazel mine or in the general area cannot be accurately determined. If the mineralized structures are Tertiary, which cannot be positively determined, the mineralization is also of a Tertiary age.

\section{CRAVIMETRIC DATA}

Observations of gravitational force in the vicinily of the Hazel mine and the Marvin-Judson prospect were made by V. E. Barnes and P. T. Flawn January $15-18,1952$. The obscrvations were made with a LaCoste-Romberg gravity meter, and the writers wish to express their gratitude to Dr. L. J. LaCoste for the loan of the instrument. Frederick Romberg examined the dala and helped make interpretations.

The observations were reduced in the usual manner for Ialitude and elevation. A combination Bouguer and free air elevation correction of $0.06 \mathrm{mg} / \mathrm{ft}$ was used, which corresponds to a densily of $2.67 \mathrm{gms} / \mathrm{cm}^{3}$. Terrain corrections were not made, even though for some stations the need for such corrections is apparent. These stations are mostly situated on the fringe of the area and have been disregarded. Tie-ins and check readings show that the probable error of any station with respect to any olher station is less than $0.04 \mathrm{mg}$ and that roost of this error is due to insufficient accuracy in obtaining elevations. "The elevations are least accurate in the areas of rough terrain which, as mentioned above, is mostly on the fringe of the surveyed area.

The localions of the stations, and the contour lines for the force are shown in figure 2 for the Hazel mine and in figure 3 for the Marvin-Judson prospect. North of the Hazcl mine fracture (fig. 2), the gravity gradient changes, steepening northward. Such a change in the vicinity of a known fault might indicate a difference of density of the rocks on opposite sides of the fault. For such a feature, however, the classical interpretation is a level gravity field on one side and a level gravity field on the other side at a different level, with a gradient in between. More gravity data should have been obtained to the south in order to give information about the regional gradient in this direction. If the gradient steepens in this direction the classical interpretation would be fulfilled. If this interpretation is correct the density contrast should be siluated at a depth of 300 or 400 feet and the denser malerial should be north of the fault. The implication of this interpretation is discussed later in "recommendations for exploration."

Another interpretation is possible because the Hazel sandstone in the vicinity of the vein is leached and less dense than normal. Density determinations made on nine specimens of the leached rock range from 2.32 to $2.60 \mathrm{gm} / \mathrm{cm}^{3}$ and the average is $2.49 \mathrm{gm} / \mathrm{cm}^{3}$, giving a density contrast of about $0.2 \mathrm{gm} / \mathrm{cm}^{3}$ with the fresh rock. The leached zone averages about 34 , feet thick, and the gravity anomaly (fig. 4) caused by such a zone will amount to about $0.1 \mathrm{mg}$. Al least part of the flattening of the gravity gradient in the vicinity of the Hazel fracture zone could be caused by the presence of leached rock.

In the vicinity of the Marvin-Judson prospect (fig. 3) a negative gravity anomaly follows the main alluvium filled valley. Removal of the regional gradient accentuales but does not change the position of the negative anomaly. Alluvium, being Icss dense than the Hazel sandstone, should cause a negative anomaly. The efiect of 10 feet of alluvium can be eslimaled by assigning a density of $1.97 \mathrm{gm} / \mathrm{cm}^{3}$ to the alluvium and comparing it to the Hazel sandstone which has a density of 2.67 $\mathrm{gmm} / \mathrm{cm}^{3}$. This gives an anomalous density of $0.7 \mathrm{gm} / \mathrm{cm}^{3}$. Therefore 15 fect of alluvium should cause a negative anomaly of the order of $0.15 \mathrm{mg}$, so that 15 feet of alluvial fill would be sufficient to produce all of the anomaly found.

However, a portion of the anomaly could be explained by a density contrast produced in some other manner. For example, the Hazel sandstone beneath the alluvium could bo breceialed and porous and thus have a lower than normal bulk density. Because 


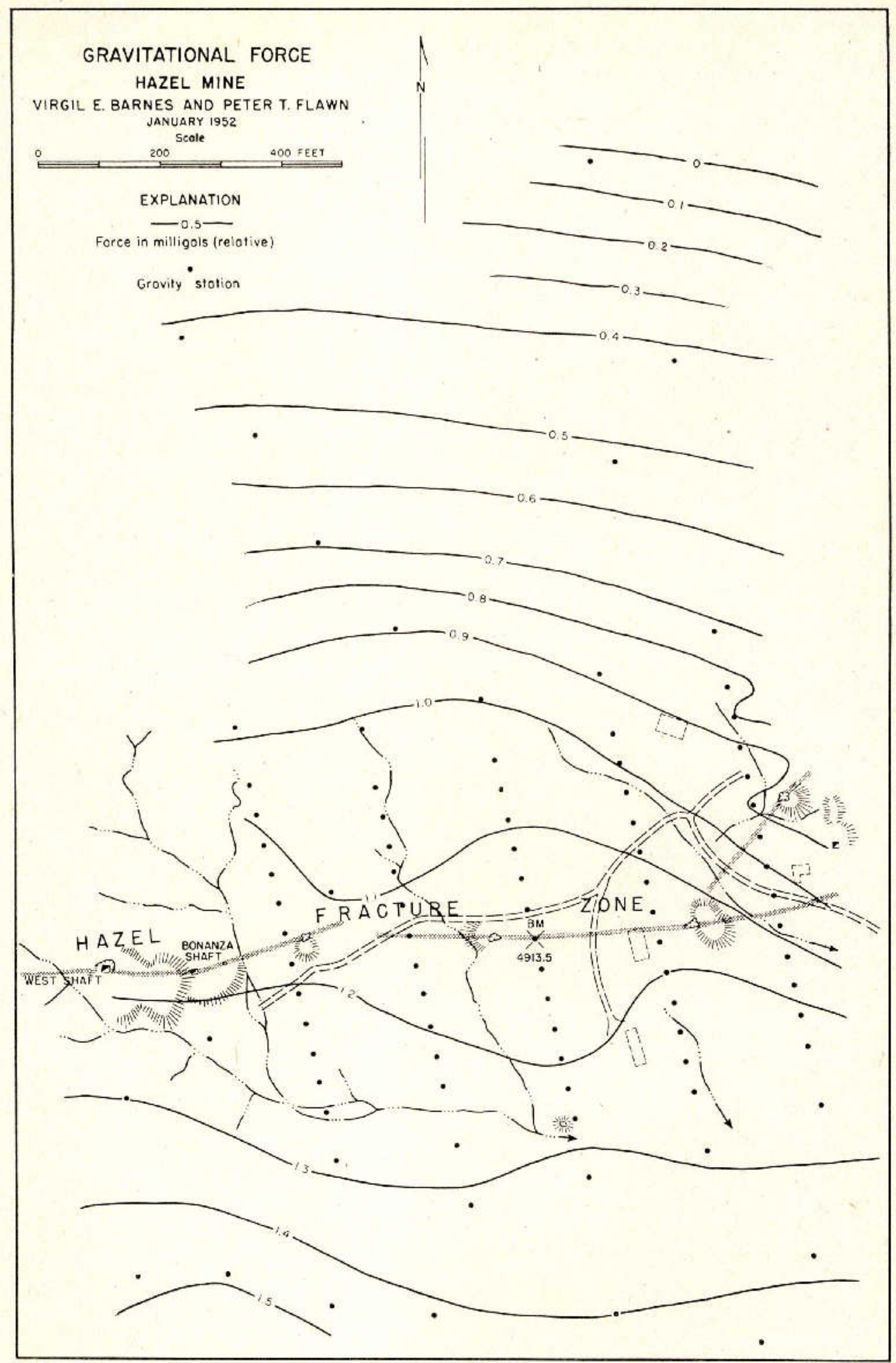

Fig. 2. Gravitational force map of Hazel mine. 
the drain is following a fracture, this might be true. There is no evidence of a density contrast on opposite sides of the fracture, and also there is no evidence of a density contrast on the opposite sides of the Hazel mine fracture in this area.

The gravity survey failed to reveal any sharp positive anomaly indicative of a concentrated heavy mass (ore minerals plus heavy gangue) in the vicinity of the Hazel mine or the Marvin-Judson prospect. However, this is not positive evidence of the absence of concealed ore bodies in these areas because the effect of local concentrations of heavy metallic sulfides and barite might be compensated by general deficiency in density of the fracture zone itself. Moreover, concentrations of copper-silver minerals that might be worked profitably may not cause a sufficient density contrast to produce a gravity anomaly. The gravity meter survey was undertaken in hopes that a near-surface lens of barite and metallic sulfides, similar to those encountered in the stopes east and west of the East shaft, could be detected.

\section{ORE RESERVES}

Through the courtesy of A. P. Williams of Van Horn, the writer was permitted to examine assay maps made about 1929 or 1930 by the World Exploration Company. According to these maps, the World Ex. ploration Company left 10,000 to 15,000 tons of broken low-grade ore ( 1 to 2 percent copper and 3 to 5 ounces in silver) in stopes between the 4th and 6th levels. This ore body apparently results from the convergence of the north and south veins and is about 25 feet wide (Sample and Gould, 1945, p. 19). Additional ore remains to be developed.

\section{INVENTORY OF THE PROPERTY}

The buildings and equipment at the Hazel mine, like the surface geology, are not prepossessing. There are three build-

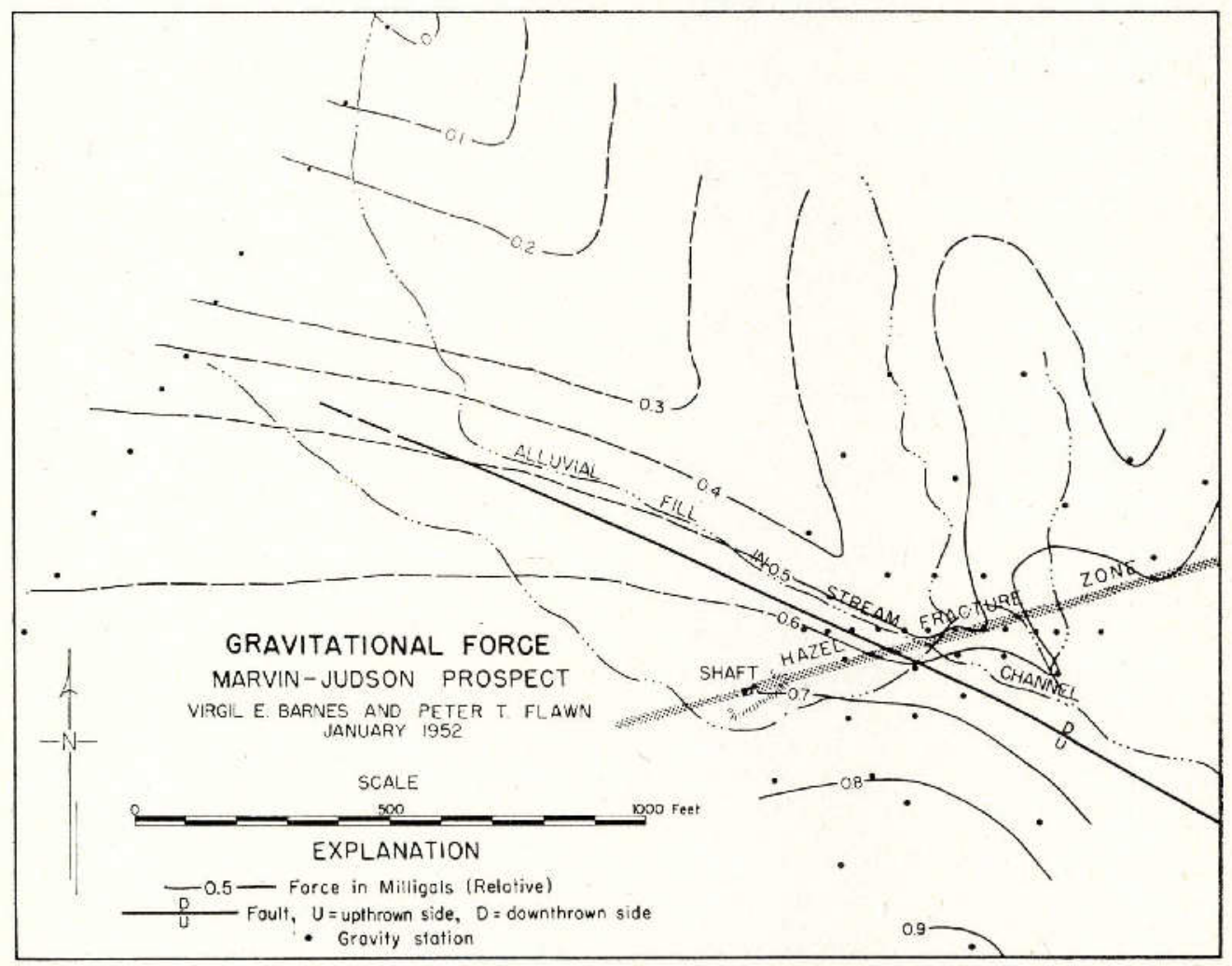

FIG. 3. Gravitational force map of Marvin-Judson prospect. 


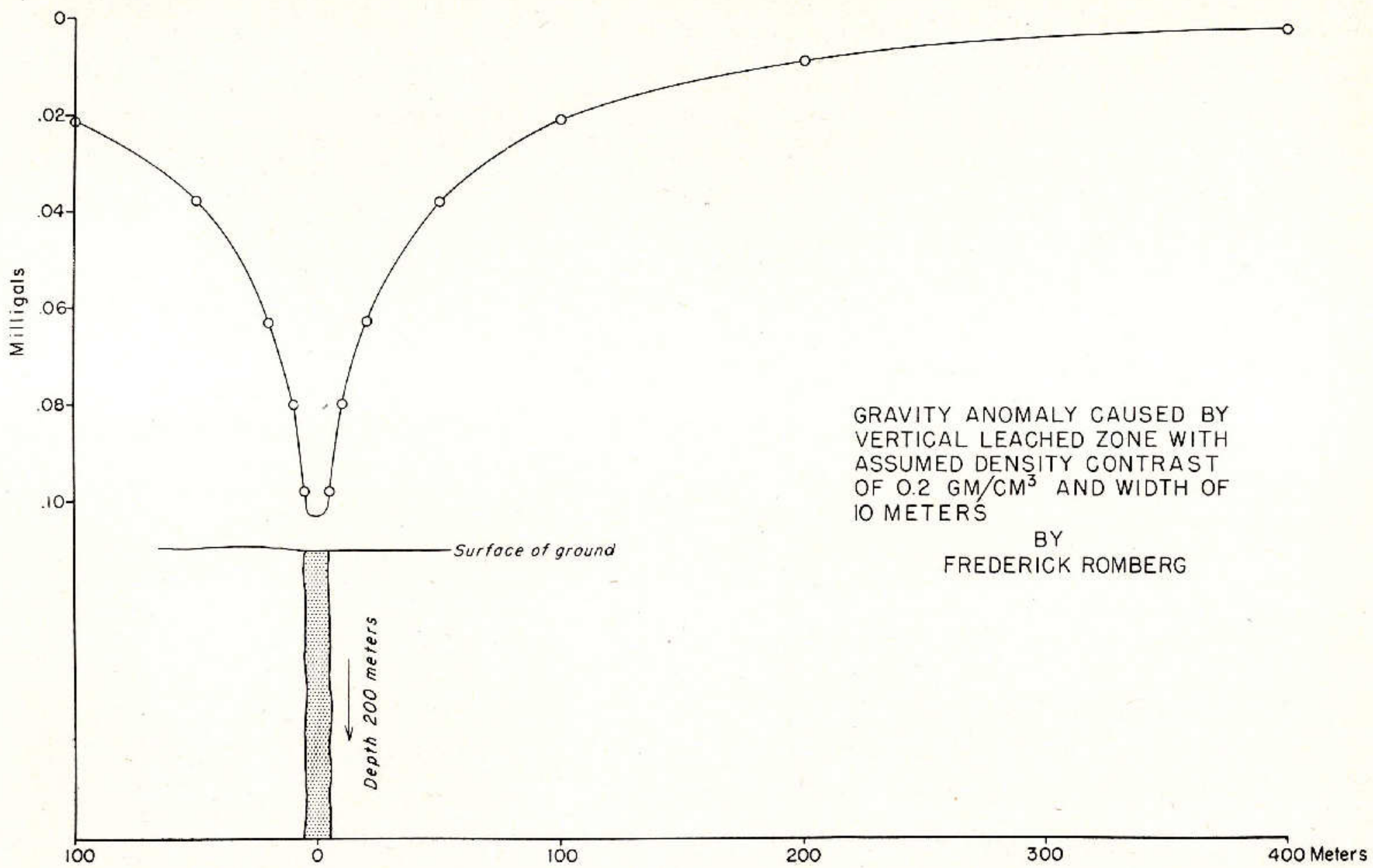

Fif. 4. Diagram of gravity anomaly caused by leached zone. 
ings standing - the power house, hoist house, and a bunk house or office, but the hoist house has served as a source of corrugated tin roofing and siding and is partly demolished. The 65-foot headframe on the East shaft has suffered from woodpeckers and boring insects and needs repair. The ore bin (150-ton) is in good condition. The following equipment remains in the hoist house:

1 Fairbanks-Morse $60 \mathrm{HP}$ gasoline hoisting engine, latest patent 1909, drum and cable (presumably there is an ore bucket at the end of the cable in the shaft)

185 HP Bessemer gasoline engine, latest patent 1899

I Ingersoll Rand compressor, Imperial type 10

1 starting engine and compressor $-8 \mathrm{HP}$ Zieg. ler Schryer gasoline engine and size 45 Worthington compressor

The power house contains:

1 Ceneral Electric 2,300-volt, 45.3 ampere alternating-current generator

1 General Electric 125-volt direct-current generator (exciter for large generator)

Control panel

At the old mill site there are two Sturtevant Mill Co. $10 \times 15$ jaw crushers and a small gasoline engine.

It is doubtful if it would be economical to repair any of the equipment on the property.

\section{RECOMMENDATIONS FOR EXPLORATION}

Large-scale mining operations at the Hazel mine ceased in 1930 for the same reason that most mines close - lack of ore. Possibly the World Exploration Company could have continued operations for a time if they had had an adequate water supply for the mill, but there is no indication that they had successfully developed an ore supply. There is a possibility that an intelligent exploration program might develop new ore bodies at the Hazel mine. Such a program should take two possibilities into consideration: first, the possibility of discovering rich silver-copper "pods" or "pockets" such as were found at shallow depth east and west of the East shaft; and, second, the possibility of discovering a large tonnage of relatively lowgrade copper ore at some depth where the vein is wide. The project should investigate (1) the undeveloped ground between the two shafts and (2) the lower levels of the mine. The mine is near both railroad and smelter, and the siliceous ore from this mine has been favorably received by the smelter in the past.

The undeveloped ground between the East and West shafts could be easily and cheaply explored by core drilling. In the area about 100 to 150 feet south of Owens' house (Pl. I) the sandstone is shattered, and, as projected from the surface evidence, a number of fractures intersect. On the surface this general area is perhaps the most favorable for prospecting, but it should be remembered that the fracture system widens underground and the vein west of this area to the West shaft should not be neglected. About a mile west of the Hazel mine is the intersection of the Hazel fracture with a northwest-trending fault (Pl. VI). The immediate vieinity of the intersection in concealed by a stream wash. West of the fault intersection is the Marvin. Judson prospect which consists of a vertical shaft cribbed with railroad ties. Bleached sandstone and barite can be seen on the dump. This area should be investigated.

The lower levels of the Hazel mine should be dewatered and examined to determine the nature of the fracture zone and the mineralization at depth. Von Streeruwitz reports a vein width of over 40 feet below a depth of 500 feet, and there is no reliable information on the nature of the mineralization at this depth. The unsubstantiated report that silver values decrease with depth while the copper values remain steady should be investigated in the light of the present world mineral situation. The lower levels of the mine were worked during the early period of the mine's history before the turn of the century when this part of Texas was little developed and costs were high. G. L. Evans (personal communication, March 1952) informed the writer that, according to a report he received, it was not economical to hoist ore valued at less than $\$ 30.00$ per ton from the lower levels of the mine.

The sandstone is relatively flat-lying in the vicinity of the mine and, based on observations made to the south by King, is probably 3,000 to 4,000 feet thick. To the south the Hazel formation is stratigraphically above the Allamoore formation, a sequence of interbedded limestone, phyl. lite, and volcanic rocks, but complex struc. 
ture makes it impossible to predict the subsurface relations in the Hazel mine area. If it is true that the East shaft bottoms in conglomerate, there is probably several thousand feet of it below the shaft; thus it would not be practicable to probe for the lower contact of the Hazel formation in hopes that it localized ore deposition. The conglomerate cannot be regarded as a more favorable host than the sandstone because it is a very hard compact rock. The unconfirmed reports on the geologic relations at the bottom of the shaft state that the vein in the conglomerate or "granite" is sharply walled and cuts cleanly through the country rock.

The interpretation of the gravity data indicates the presence of a heavy mass on the north side of the fracture at a depth of 300 to 400 feet. No such mass is mentioned in the previous reports. Possibly it is a conglomerate layer (the majority of frag. ments within the conglomerate are Allamoore limestone which would make a rock with higher density than the sandstone) that has been raised along the upthrown side of the fault. An exploration program should include investigation of this anomaly.

\section{BIBLIOGRAPHY}

Evans, G. L. (1943) Progress report on copper investigations: Univ, Texas, Bur. Econ. Geol., Min. Res. Cir. 24, 6 pp.
Krac, P. B. (1935) Outline of structural development of Trans-Pccos Texas: Bull. Amer. Assoe. Petr. Geol., vol. 19, pp. 221-26l.

Van Horn (1940) 0]der rocks of the gion, Texas: Bull. Amer. Assoc. Petr. Geol., vol. 24, pp. 143-156.

(1949) Regional yeologic: map of parts of Colberson and Hudspeth counties, T'exas: U. S. Geol. Survey Oil and Gas Jnv, Prelim. Map 90.

- ... - Unpublished notes released by the U. S. Geological Survey.

, and Knirht, J. B. (1944) Sierra Diablo region, Culberson and Hudspeth countics, Texas: U. S. Geol. Sarvey Oil and Gas Inv, Prelim. Map 2.

J. B. (1945) Ge, King, R. E, and Knight, Paso and Hudspeth connties, Texas: U. S. Geol. Survey Oil and Gas Inv., Prelim. Map 36, sheet 1 .

Richaroson, G. B. (19I4) Description of the Van Horn quadrangle: U. S. Geol. Survey Geol. Atlas, Von Iorn Folio (No. 194), 9 pp.

SAmile, R, D., and Gould, F. F. (1945) Geology and ore deposits of the Allamoore- $V_{\text {an }}$ Horn copper district, Hudspeth and Culberson counties, Texas: U. S. Geol. Survey Open-File Report, 21. pp.

StrRfFruwitz, W. IT. YoN (1890) Geology of Trans-Pecos Texas: Texas Geol. Survey, 1st Ann. Rept. (1889), pp. 224-235.

and (1891) Rcport on the geology and mineral resources of Trans-Pecos Texas: Texas Geol. Survey, 2d Ann. Rept. (1890), pp. 665-7].3.

(1892) Trans-Pecos 'l'exas: Texas Ceol, Survey, 3d Anr. Rept. (1891), pp. $383-389$.

Texas Genl. Survey, 4th Ann. Rept. (1892), pp. 141-7.67. 


\section{INDEX}

agse of faulting: 18

Allamoore formation: 11,12

limestune: 11, 20

Allamoore-Van Horn copper district: antimony: 8,14

argentite: 8,14

Assays: 14

maps: 18

barite: 14, 1.5, 16, 18, 20

Barnes, V. E.: 7, 16

Baylor Mountrins:

Beach Mountains: 5, 11

Bean, Jim: ?

Bonanga shaft: 11

bornite: 14

ealcite: 15

chalcocite: 8, 14, If

haleopyrile: 14,15

Chínati Mountains: 8

Clifford, $H_{.} J_{+} \neq 7$

copper: $10,18,20$

covellite: 14

Gulberson County: 5

Diablo Plateau: 7

Drunzer, M. F.: 8, 9

East: whaft: $8,10,13,15,18,20,21$

east-west fracture rone: is

il Paso smelter: 5

cquipment: 8, 18-19

Evans, G. I..: ?

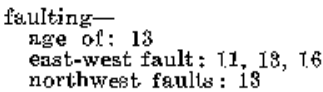

yalena: 14

gangue: $7,8,14,15$

gravitational force: 17,18

travity nnomaly: 18

meter, Lacoste-Irombery: 16

Hazel formation: 11, 13, 20, 21

fxacture zone: $13,15,16,17,1.8,20$

Mining and Millints Cotnpany : ?

sandstone: $11,15,16$

headframe: $11,15,16$

I udspeth Comnty: 5

Hueco limestone: 11

inclined ehafl: 11

King, $P, B_{+} \div 7$

LaCoste-Romberg gravity meter: 16 loached zone: 19

lead : 8,14 mareasite: 14

Marvin-Jurson prospeet: $6, .1,13,16,18,20$

Melton, B.: 6

Middle shaft: 8,11

mill : 8,20

Millicen Hills: 13

mine timber: 5

mining melhod: 8, 10

Mohawk mine: 11

northwest faults : 18

ore-

minerajs

arkentite: 8,14

bornite: 14

chaleocite: $8,14,16$

native silver: $8,10,14,18,20$

parngenesis of: $14,15,16$

tetrahsodrite-tennantite: 14,1

mode of occurrence of: $7,18,15$

reserves of: 18

tenor of: $7,8,10,14,20$

Owens, T. R.: ?

parafenesis of ure minerals: $14,15,16$

Pecos prospect: 13

Phinney $\mathrm{C} s: \mathrm{T}$

principgl ores:8, 14

prodiction: $5,6,7,8,9,10$

prospect, Marvin-Judson: 6, 1.t, $13,16,18,20$

Pecos: 13

Pueblo, Colorado, smeltor: 7

pyrite: 14

quartz: 14,15

Quitman Mountains: 8

Rowbers', Frederick: 7, 16

Sicrra, Caxrizo: 8

Sierra Diablo: $5,8,11,13$

silver: $8,10,14,18,20$

smetter: 11,20

Fl Paso:

Fueblo, Colorado: 7

Stícher, R. B.: :

stopes: $10,11,14,18$

Streeruwite Hille: 13

tenmantitc: 14,15

tr.trahedrite: $8,1.4,15$

-tennautíte: 14, 15

timber, mine: $\mathbf{5}, 8,71$

Van Horn sandstone: 11

water $\div 5,6,8,9,10,11,20$

West shaft: : $8,11,14,20$

stope: $10+14$

William, A. T.: 6, 9, 15, 18

Winn, W. H.;

World Exploration Company: 6, 7, 8, 10, 18 


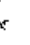





\section{NOV 211952}

